\title{
Przekaz symboliczny i podejście User Experience na przykładzie serwisów internetowych teatrów krakowskich ${ }^{1}$
}

\author{
Magdalena Zych \\ Wydział Zarzadzania i Komunikacji Społecznej, Uniwersytet Jagielloński
}

\begin{abstract}
Abstrakt
Cel/Teza: Głównymi celami były opis przekazu symbolicznego oraz ocena User Experience serwisów teatrów krakowskich. Serwisom WWW przypisano możliwość wspomagania realizacji pozainstrumentalnych potrzeb użytkownika.

Koncepcja/Metody badań: Zastosowano metodologię jakościową. Materiał gromadzono za pomocą TAP i techniki inspirowanej procedurą ZMET. W badaniu wzięło udział dziesięciu użytkowników związanych ze środowiskiem teatralnych. Zbadano serwisy dziewięciu teatrów. Materiał poddano analizie tematycznej.

Wyniki i wnioski: Przekaz symboliczny opisano na przykładzie serwisu Teatru Scena STU. Za czynniki wpływające na przekaz symboliczny uznano cechy indywidualne użytkownika, nastawienie emocjonalne i elementy wnoszone przez interakcję użytkownik-serwis. Stwierdzono, że pozytywna ocena użyteczności niekoniecznie przekłada się na oczekiwany przekaz symboliczny.

Oryginalność/wWartość poznawcza: Artykuł stanowi przyczynek do badań nad zależnościami między przekazem symbolicznym, przekazem informacyjnym oraz użytecznością serwisów WWW, dotąd nieporuszanymi na gruncie informatologii.
\end{abstract}

\section{Słowa kluczowe}

Funkcja serwisu WWW. Przekaz symboliczny. Serwis WWW teatru. User Experience. Użyteczność.

Otrzymany: 26 czerwca 2017. Zrecenzowany: 7 lipca 2017. Zaakceptowany: 31 sierpnia 2017.

\section{Wprowadzenie}

Jednym z popularnych, choć wciąż niespójnych, podejść w badaniu i projektowaniu serwisów WWW jest User Experience. Część badaczy kwestionuje nawet możliwość projektowania User Experience, twierdząc, iż można co najwyżej projektować dla User Experience (Bargas-Avila \& Hornbæk, 2011, 1; Diefenbach \& Hassenzahl, 2011, 461). W tym artykule postanowiono skorzystać z podstawowych osiągnięć UX, nie zamykając się jednak na związany z tym aparat pojęciowy i metodologiczny. W centrum badań ustawiono przekaz symboliczny serwisu WWW. Jest to konsekwencją założenia, że serwisy WWW mogą

1 Artykuł powstał na podstawie pracy magisterskiej autorki pt. Przekaz symboliczny i podejście User Experience na przykładzie serwisów internetowych teatrów krakowskich napisanej w 2016 r. pod kierunkiem dr hab. Marii Próchnickiej w Instytucie Informacji Naukowej i Bibliotekoznawstwa Uniwersytetu Jagiellońskiego. Praca ta uzyskała II nagrodę w konkursie na najlepsza pracę magisterską Nagroda Młodych SBP w okresie obejmującym trzy lata akad.: 2013/14, 2014/15 i 2015/16 [red.]. 
wspierać realizację poza-instrumentalnych potrzeb użytkownika. Przekaz symboliczny stanowi zagadnienie niezbadane na gruncie informatologii, zaś przeprowadzone badania empiryczne mogą stanowić przyczynek do dalszych badań w kierunku określenia relacji przekazu symbolicznego z użytecznością oraz przekazem informacyjnym.

\section{Przedmiot i cel badań}

Przedmiotem badań jest podejście User Experience (UX) oraz przekaz symboliczny serwisów internetowych. Badanie miało charakter eksploracyjny i zostało przeprowadzone na przykładzie serwisów WWW teatrów krakowskich.

Głównymi celami badań były: opis przekazu symbolicznego oraz ocena User Experience wybranych serwisów internetowych. W niniejszym artykule User Experience rozumiane jest jako system obejmujący wartości pragmatyczne i hedonistyczne. Przyjęto, że wartości pragmatyczne charakteryzowane są m.in. przez funkcjonalność (ang. functionality) oznaczającą zakres dostępnych operacji i poprawność ich działania (Laskowski, 2011, 2192) oraz użyteczność (ang. usability), która w tej pracy oznacza łatwość obsługi czegoś i zakładaną możliwość zaspokojenia instrumentalnych potrzeb użytkownika. O wartościach hedonistycznych piszą m.in. Sarah Diefenbach oraz Marc Hassenzahl, których zdaniem idea wartości hedonistycznych wciąż ewoluuje (Diefenbach \& Hassenzahl, 2011, 461). W piśmiennictwie naukowym wartości hedonistyczne UX, zwane również wartościami nie-instrumentalnymi, opisywane są za pomocą następujących haseł:

- afiliacja/przynależność/interakcje społeczne (Diefenbach \& Hassenzahl, 2011, 461; O’Brien, 2010),

- eskapizm (O’Brien, 2010, 3; Wu \& Holsapple, 2014, 82),

- $\quad$ estetyka (Bargas-Avila \& Hornbæk, 2011, 1; Coursaris et al., 2010, 1; Nawaz, 2013, 49),

- ewokacja - odnosi się do symbolicznego znaczenia oraz potencjału w przywoływaniu wspomnień (Partala \& Kallinen, 2012, 26),

- identyfikacja - możliwość ekspresji siebie za pomocą przedmiotów, które się posiada i/lub z których się korzysta (Helfenstein, 2012, 191; Karapanos et al., 2009, 730; Partala \& Kallinen, 2012, 25; Wu \& Holsapple, 2014, 82),

- piękno (Bargas-Avila \& Hornbæk, 2011, 2; Diefenbach \& Hassenzahl, 2011, 462; Karapanos et al., 2009, 735),

- przyjemność (Karapanos et al., 2009, 735; O’Brien, 2010; Schuitema et al., 2013, 40),

- radość z użytkowania (Bargas-Avila \& Hornbæk, 2011, 2; Schuitema et al., 2013, 40),

- reakcje afektywne/emocje (O’Brien, 2010; Schuitema et al., 2013, 40; Wu \& Holsapple, 2014, 82),

- rozwój osobisty (Bargas-Avila \& Hornbæk, 2011, 2; Karapanos et al., 2009, 730; Partala \& Kallinen, 2012, 25),

- $\quad$ samorealizacja (Bargas-Avila \& Hornbæk, 2011, 1; Nawaz, 2013, 49),

- stymulacja, wyzwanie (Bargas-Avila \& Hornbæk, 2011, 2; Diefenbach \& Hassenzahl, 2011, 461; O’Brien, 2010; Karapanos et al., 2009, 730; Partala \& Kallinen, 2012, 25),

- zabawa, rozrywka (Diefenbach \& Hassenzahl, 2011, 462; O’Brien, 2010; Coursaris et al., 2010, 1-2; Helfenstein, 2012, 191; Wu \& Holsapple, 2014, 82),

- zaskoczenie (Bargas-Avila \& Hornbæk, 2011, 2). 
Przekaz symboliczny serwisu internetowego rozpatrywany jest w niniejszym artykule bardzo wąsko, tj. jako możliwość oddawania charakteru teatru przez jego serwis WWW. Poza ogólnymi wynikami badań przeprowadzonych na serwisach WWW dziewięciu wybranych krakowskich teatrów, przedstawiono opis przekazu symbolicznego jednego z analizowanych serwisów - Krakowskiego Teatru Scena STU.

\section{Stan badań}

Analizę i krytykę piśmiennictwa naukowego przeprowadzono na podstawie publikacji w językach polskim lub angielskim, opublikowanych w latach 2009-2015. W uzasadnionych przypadkach włączono też starsze publikacje naukowe, których wartość merytoryczna przydatna była do zaprojektowania procedury badawczej lub czynienia ustaleń terminologicznych. Gromadzone były publikacje dotyczące User Experience, oceny serwisów internetowych, zwłaszcza serwisów teatrów oraz instytucji zbliżonych, jak również publikacje poświęcone komunikacji teatru z interesariuszami. Największą wagę przypisano publikacjom zawierającym wyniki badań empirycznych. Łącznie uwzględniono 81 publikacji.

Kwerendą wyszukiwawczą objęto źródła komercyjne i Open Access. Wśród wykorzystanych źródeł znalazły się m.in.: bibliografie (np. Polska Bibliografia Bibliologiczna (1995-); Przewodnik Bibliograficzny (MARC 21, 1973), komercyjne bazy piśmiennictwa naukowego (np. Academic Search Complete; Library, Information Science \& Technology Abstracts), wyszukiwarki (np. Google Scholar; OAIster), archiwa dziedzinowe i repozytoria instytucjonalne (np. E-LIS; Queensland University of Technology ePrints Archive), katalogi czasopism (Directory of Open Access Journals; Portal Czasopism Naukowych), biblioteki cyfrowe (Federacja Bibliotek Cyfrowych) oraz CEON Biblioteka Nauki. Preferowanym trybem dostępu do zasobów było przeszukiwanie. Nie zawsze było ono możliwe ze względu na funkcjonalności dostępne w poszczególnych źródłach. Wyszukiwanie najczęściej prowadzono za pomocą zapytań w formie różnych wariacji składających się z następujących słów kluczowych: „user experience”, „theater website”, „website”, „theatre”, „usability”, „hedonic”, „hedonic quality”, „hedonic value”, „symbolic”, „symbolic quality”, „performing arts”, „evaluation”, „funology”, „branding” oraz ich polskich odpowiedników. Podczas tworzenia zapytań, w miarę oferowanych w źródle możliwości, korzystano z pomocy wyszukiwawczych, takich jak np. słowniki kontrolowanej leksyki oraz łączenie wyrażeń/słów kluczowych operatorami logicznymi.

W wyniku analizy piśmiennictwa zidentyfikowano dwie luki. Po pierwsze niewiele jest publikacji poświęconych empirycznym badaniom serwisów WWW teatrów, zwłaszcza prowadzonych z udziałem użytkowników, toteż gromadzono publikacje dotyczące oceny innych serwisów internetowych, przy czym starano się, aby owe serwisy były zbliżone tematycznie do serwisów teatrów lub należały do instytucji podobnych do teatrów. Pod tym względem przeważają badania serwisów muzeów, o których pisali m.in. Jessie Pallud, Detmar W. Straub (Pallud, Straub, 2014), Mohd S. Yamin i Eswati A. Jaafar (Yamin \& Jaafar, 2013) oraz Debra A. Riley-Huff (Riley-Huff, 2009). Natomiast za najbardziej wartościową publikację, ze względu na badany serwis internetowy, uznano The Royal Opera House Website Evaluation Report (Trosheva, 2013). W projektowaniu własnej procedury badawczej przydatne okazały się publikacje dotyczące komunikacji teatru z widzami, w tym badanie 
nawyków konsumenckich związanych z nabywaniem biletów na spektakle oraz rola emocji w tym procesie (Troilo et al., 2014), komunikacja teatru z publicznością za pomocą Internetu (Turrini et al., 2012), strategia pozyskiwania widzów teatralnych z wykorzystaniem narzędzi komunikacji cyfrowej (Kossecki \& Świerczyńska-Kaczor, 2014) oraz badanie publiczności i wizerunku teatrów warszawskich (Siwiak et al., 2013).

Druga luka dotyczy przekazu symbolicznego serwisów internetowych, chociaż odszukać można publikacje, których autorzy analizują m.in. serwisy WWW, odwołując się do symbolicznych kategorii. Nie tłumaczą jednak, jak definiują bądź interpretują kategorie symboliczne, którymi się posługują. Nieliczni autorzy, którzy stosowali określenie „symboliczny" w odniesieniu do przedmiotu swych badań, charakteryzowali go za pomocą następujących określeń: znaczenie barw (Hernik, 2012), wizerunek (Helfenstein, 2012, 191), prestiż/duma wynikające z użytkowania marki lub produktu (Helfenstein, 2012, 191; Saucken \& Gomez, 2014, 653), a także tożsamość społeczna (Schuitema et al., 2013, 40). Dodatkowo część atrybutów (np. ewokacja, ekspresja siebie, samorealizacja) bywa przypisywana zarówno do sfery symbolicznej, jak i do wartości hedonistycznych UX. W wyniku analizy piśmiennictwa zidentyfikowane trzy publikacje, w których omówione zostały badania układu składającego się z wartości hedonistycznych, pragmatycznych i symbolicznych (Bhui \& Ibrahim, 2013; Hernik, 2012; Schuitema et al., 2013). Na ich podstawie nie udało się jednak wyłonić spójnego modelu uwzględniającego UX i przekaz symboliczny.

\section{Zastosowana metodologia}

W omówionych w artykule badaniach zastosowano metodologię jakościową. Materiał empiryczny gromadzono za pomocą symultanicznej wersji think-aloud protocol (TAP) oraz techniki inspirowanej procedurą Zaltman Metaphor Elicitation Technique (ZMET). W badaniu wzięło udział dziesięciu użytkowników związanych ze środowiskiem teatralnym. Byli wśród nich aktorzy, pracownicy teatrów oraz widzowie.

W piśmiennictwie naukowym odnotowuje się trzy warianty TAP: concurrent (wersja symultaniczna), retrospective (retrospektywna) oraz constructive interaction, zwana również co-discovery learning (AlRoobaea et al., 2013, 92; Elling et al., 2012; Haak et al., 2009, 194; Szóstek 2011, 97). W omawianych badaniach zastosowano symultaniczną wersję TAP, co oznacza, iż każdy z użytkowników proszony był o werbalizację myśli, odczuć i działań $\mathrm{w}$ trakcie indywidualnej interakcji z analizowanymi serwisami internetowymi.

ZMET wywodzi się z badań marketingowych i służy do mapowania modeli mentalnych użytkowników, także z uwzględnieniem stanów afektywnych. Istnieje wiele wariantów ZMET, które różnią się liczbą i ułożeniem poszczególnych etapów badania. Zdaniem Geralda Zaltmana, twórcy ZMET, kluczowym elementem jest multisensoryczność badania, osiągnięta m.in. przez bazowanie na opowieści o materiałach wizualnych (Zaltman, 1996, 13). W badaniach autorki ZMET posłużyła jako inspiracja do wypracowania własnej procedury, w której każdy z użytkowników proszony był o krótką opowieść o wcześniej zgromadzonych przez siebie obrazach (od 8 do 12), przedstawiających wyobrażenie o wybranym teatrze krakowskim. Następnie zadawane były pytania dotyczące zaprezentowanych obrazów, dotyczących np. najbardziej znaczących obrazów oraz skojarzeń, których nie udało się oddać za pomocą materiałów wizualnych. 
Wybór serwisów WWW poddanych badaniu składał się z kilku etapów. Za kryteria konieczne przyjęto posiadanie przez serwis polskiej wersji językowej oraz jego przynależność do teatru krakowskiego, rozumianego jako teatr z siedzibą w Krakowie, niezależnie od organizatora oraz posiadania własnych scen teatralnych.

Pierwszą kwerendę przeprowadzono w marcu 2015 r. Korzystając z wyszukiwarki Google, w polu wyszukiwania prostego wpisano dwa terminy: „teatr” i „Kraków”. Zapoznano się z trzema pierwszymi stronami wyników. Następnie kompletowane zestawienie serwisów uzupełniono na podstawie zawartości internetowych repertuarów teatralnych oraz katalogów DMOZ i PKT. Opisaną kwerendę powtórzono w listopadzie 2015 r. Po tej aktualizacji na liście znalazło się 21 serwisów internetowych. Ostatecznie doboru dziewięciu serwisów poddanych badaniu empirycznemu dokonano nakładając na otrzymaną listę serwisów następujące filtry: typologię widowisk teatralnych według Christophera Balme’a (Sajkiewicz, 2010, 29), aktualną strukturę teatralnej mapy Krakowa oraz interfejs serwisu WWW, w tym układ serwisu.

Decyzja, które serwisy, spośród dziewięciu zaproponowanych, były uwzględniane podczas sesji należała już do użytkownika. Najpierw użytkownik wybierał jeden teatr, dla którego kompletował obrazy oddające subiektywne skojarzenia związane z tym teatrem. Ten wybór teatru determinował pierwszy serwis, który później poddany był badaniu. Następne dwa serwisy wybierane były przez użytkownika za pomocą planszy, na której znajdowały się niepodpisane, kolorowe zrzuty ekranowe stron głównych wszystkich dziewięciu serwisów, każdy w formacie A4. Przyjęto zasadę: użytkownik dokonywał wyboru tylko jednego serwisu z każdej z trzech grup (pierwsza liczba w nawiasie oznacza, ile razy użytkownicy wybrali teatr do części z obrazami; druga odnosi się do wyboru serwisu z planszy):

Gr. 1. Teatry dramatyczne: Krakowski Teatr Scena STU $(3+1)$, Narodowy Stary Teatr im. Heleny Modrzejewskiej $(2+3)$, Teatr im. Juliusza Słowackiego $(0+1)$.

Gr. 2. Teatry dramatyczne: Teatr Barakah $(1+1)$, Teatr Łaźnia Nowa $(1+4)$, Teatr Odwrócony $(1+2)$.

Gr. 3. Teatry muzyczne i lalki: Krakowski Teatr Variété (0+4), Opera Krakowska (1+1), Teatr Groteska $(1+3)$.

Na początku badania użytkownik opowiadał o każdym ze zgromadzonych wcześniej materiałów wizualnych. Po zakończeniu wypowiedzi zadawane były pytania do przedstawionego zbioru obrazów. Po wybraniu dwóch pozostałych serwisów, użytkownik wskazywał kolejność, w której chciałby dokonywać interakcji z serwisami. W każdym z serwisów użytkownik wykonywał 12 zadań. Po zbadaniu trzech serwisów zadawane były ogólne, podsumowujące pytania. Sesję z każdym z użytkowników rejestrowano w formie audio, od momentu prezentowania obrazów, do udzielenia odpowiedzi na ostatnie z pytań podsumowujących. Nie przewidziano limitu czasowego. Całość zgromadzonego materiału poddano transkrypcji oraz analizie tematycznej, którą usprawniono programem QDA Miner.

\section{Opis przekazu symbolicznego serwisu Krakowskiego Teatru Scena STU}

Serwis Teatru STU analizowany był czterokrotnie, przy czym trójka użytkowników zdecydowała się zbierać obrazy oddające wyobrażenia związane z Krakowskim Teatrem Scena STU. Wyodrębniono cechy wspólne tego zbioru, które przedstawiono w sposób graficzny (Rys. 1). Są to odwołania do konkretnych spektakli oraz „Benefisów”, lokalizacji teatru, 
fasady budynku, wnętrza teatru, a także osób związanych z Teatrem, wśród których powtarzającym się nazwiskiem był Jerzy Trela. Powtarzało się także nawiązywanie do sposobu promocji Teatru, w tym odwołania do telebimu znajdującego się na fasadzie Teatru, na którym wyświetlane są zapowiedzi spektakli. Przywołany został też logotyp i jego konsekwentne stosowanie na materiałach promocyjnych Teatru. Natomiast najbardziej znaczącymi obrazami w kontekście Teatru Scena STU były obrazy przedstawiające Jerzego Trelę i historię Teatru - w kontekście realizacji marzeń aktorskich (dla użytkownika 1A1) oraz fasada budynku (dla użytkowników 4W2 i 10W5).

Rys. 1. Mapa myśli przedstawiająca obrazy do Krakowskiego Teatru Scena Stu zgromadzone przez użytkowników 1A1, 4W2 i 10W5

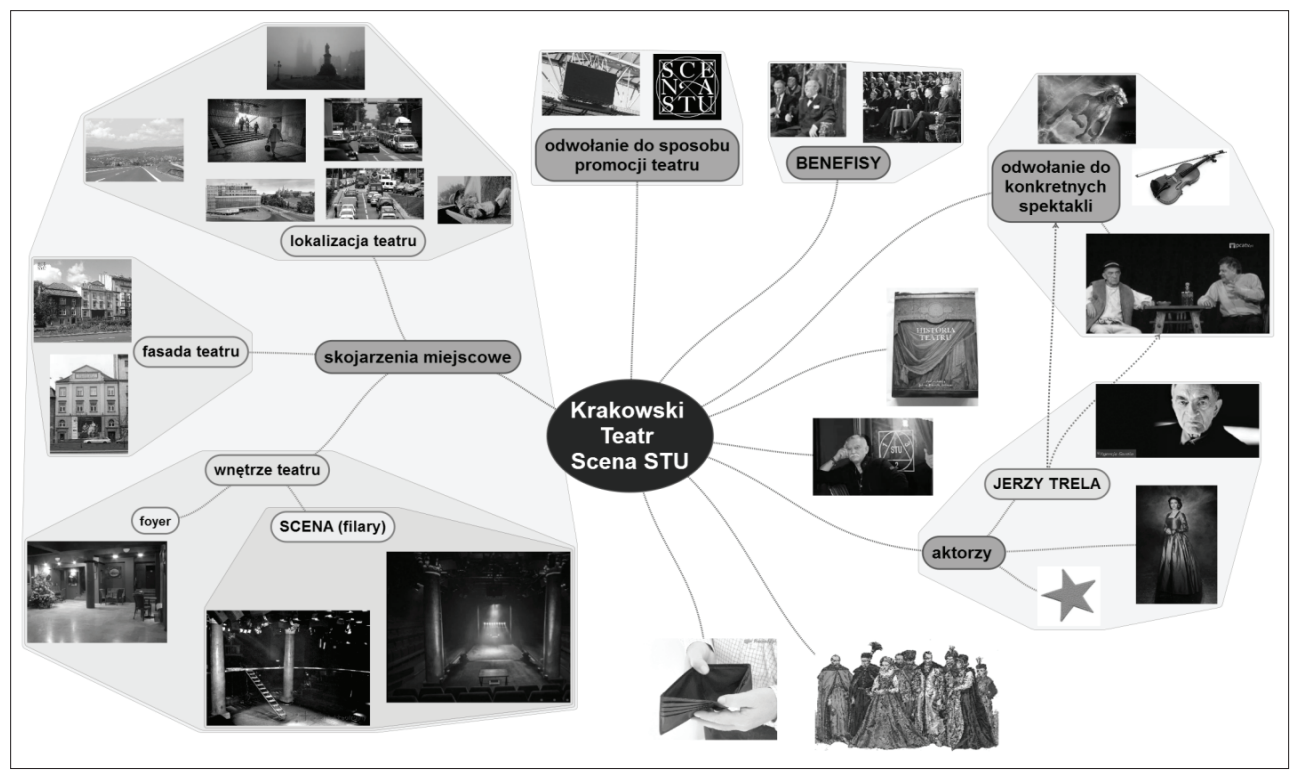

Na podstawie wypowiedzi użytkowników oceniających serwis Krakowskiego Teatru Scena STU można przyjąć, iż powierzchowne skojarzenia z Teatrem udało się dobrze oddać w serwisie. Benefisom poświęcona została osobna zakładka w menu, użytkownik 10W5 wskazał elementy potwierdzające w serwisie skojarzenia ze znanymi aktorami oraz wysokimi cenami biletów, zaś na stronie głównej pojawiają się zdjęcia sceny, co jest dosłowną reprezentacją tego elementu świata realnego w rzeczywistości wirtualnej, a - jak zauważyli użytkownicy 4W2 oraz 10W5 - układ serwisu także nawiązuje do wyglądu sceny. Z opisu sceny Teatru przedstawionego przez użytkownika 4W2 wyłania się obraz kwadratu oraz bliskiego kontaktu widzów z aktorami. W serwisie nie udało się odszukać nawiązania do wspomnianego bliskiego kontaktu z aktorami, o którym podczas opowieści o Teatrze STU mówił także użytkownik 7W4, natomiast silnie odwzorowana została geometria sceny, do której odnoszą się wypowiedzi Q1 i Q2 oraz Q3 dotyczące układu serwisu.

(Q 1) „Bo scena jest charakterystyczna w Teatrze Stu, prawda? To znaczy widzowie mają bardzo bliski kontakt z aktorami. Siedzą niemalże koło nich i otaczają ich $\mathrm{z}$ trzech, tą scenę z trzech stron, więc ten kontakt jest taki niemalże namacalny. 
To jest taki kwadracik, w którym się wszyscy spotykają" - użytkownik 4W2 o Krakowskiem Teatrze Scena STU.

(Q 2) „Jest to teatr krakowski. Jest to teatr kameralny, moim zdaniem, ale tego tutaj nie widzę, aczkolwiek ta strona... ona, jej ciemne tło powoduje, że no moje skojarzenia są ewidentne właśnie z tym wnętrzem Teatru, z tym kwadratem, z tą publicznością otaczającą scenę - to, jak najbardziej budzi moje skojarzenia" użytkownik 4W2 o serwisie Krakowskiego Teatru Scena STU.

(Q 3) „[C]ały serwis jest, tak jakby, według mnie... ładnie poukładany w takie... prostokąty... (...) cały serwis jest oparty na takich prostokątach, przynajmniej ja tak widzę: jest prostokąt, nazwijmy to z nagłówkiem; prostokąt ze zmieniającymi się reklamami najprawdopodobniej najbliższych spektakli; jest kolejny prostokąt aktualności; prostokąt z możliwością zamawiania biletów, a także newsletter też prostokąt. I stopka - prostokąt, także... Ten kwadrat, który de facto też jest prostokątem - idealnie pasuje" - użytkownik 10W5 o serwisie Krakowskiego Teatru Scena STU.

Odnotowano trudność z odwzorowaniem głębszych skojarzeń. W serwisie nie udało się odnaleźć elementów wskazujących na krakowski charakter Teatru, o którym mówił użytkownik 4W2. Natomiast wątpliwości użytkownika 7W4, co do charakteru Teatru STU budził zamieszczony w serwisie WWW opis:

(Q 4) „Rodzina STU, komuna teatralna, czołówka światowej alternatywy, enklawa kontestacji - no, to <śmiech > To pierwsze zdanie jest wątpliwe. <śmiech > W moim odbiorze, więc ja mówiłem raczej co innego. Tak, bo czołówka światowej alternatywy - no, początki takie były... początki takie były. Enklawa kontestacji, kontrkultury - no to, co tam by Klata musiał pisać, no?" - użytkownik 7W4.

Dla użytkownika 1A1 szczególnie znaczące były dwa filary znajdujące się na scenie, które przywołały myśl o teatrze antycznym i znajdują odzwierciedlenie w zdjęciach prezentowanych w serwisie:

(Q 5) „To te... Bo w środku są takie właśnie, o takie! Takie filary. I bardzo mi się to kojarzy z jakimś starym, jakimś greckim, antycznym teatrem. Miejscem, właściwie sceną jakąś taką antyczną. Takie coś mam, takie mam sobie też skojarzenie. Po prostu ten środek. Środek Teatru Stu. Te filary. Tak mi się fajnie kojarzą, tak. Ale bardzo lubię w ogóle, ja... jakoś tak ten grecki teatr mi się zawsze strasznie podobało. Takie... Także pozytywne, pozytywne bardzo skojarzenie" - użytkownik 1A1 o Krakowskim Teatrze Scena STU.

Równocześnie ów antyczny teatr, a przez to i Teatr STU, był przez użytkownika 1A1 bardzo pozytywnie kojarzony, na co nałożyły się inne skojarzenia zobrazowane m.in. przez wytworne, eleganckie kostiumy. Natomiast ogólne wrażenie z interakcji z serwisem WWW, z powodu napotkanych trudności z zakresu użyteczności, pozostawiło użytkownika 1A1 $\mathrm{z}$ poczuciem dysonansu:

(Q 6) „Właśnie od teatru bym oczekiwał takiego klasycznego przedstawienia, klasycznego teatru, klasycznej sceny, z takimi filarami greckimi, co jest w Teatrze Stu. Po serwisie.... <śmiech > ciężko jest mi to później określić, bo jest taki niedopracowany ten serwis. (...)" - użytkownik 1A1.

Gdyby natomiast rozpatrywać serwis Teatru STU tylko w zakresie estetyki, podstawowe skojarzenia z tym Teatrem, zgodnym zdaniem użytkowników zostały oddane. 
(Q 7) „Mnie taka - tak samo sam teatr określiłem jako wyrafinowany, tak samo strona też mi się wydaje taka stonowana, bardzo z klasą" - użytkownik 10W5 o serwisie Krakowskiego Teatru Scena STU.

(Q 8) „Tak. No jest trochę, można powiedzieć, że jest ciemno. Ciemno, smutno. No, ale tak właśnie teatralnie. W jakiś inny świat się można przenieść... Brązowa, stonowana. Taka elegancka. Myślę, że do takiego teatru, który się kojarzy jednak z elegancją, a nie z jakimiś takimi... mówiąc [w] cudzysłowie, nowoczesnymi spektaklami, to jest ok, tak. Tak kolorystyka odpowiada" - użytkownik 1A1 o serwisie Krakowskiego Teatru Scena STU.

(Q 9) „Ogólnie rzecz biorąc, nie lubię czarnego tła, ale akurat w tym przypadku w ogóle mi nie przeszkadza. $<\&$ Dlatego, że jest to teatr, czy...-\&> Dlatego, że to jest TEN teatr. Bardzo pasuje, moim zdaniem. Ta strona została przygotowana w sposób przemyślany. $<\&$ Chce Pani to rozwinąć jakoś, czy już na tym chce Pani zakończyć?\&> No właśnie jak widzę, jak widzę wnętrze tego teatru, właśnie sfotografowane w taki sposób, no to widać wyraźnie, że tam jest właśnie tak: czarno i tylko jedna smuga światła puszczona na środek sceny i ja właśnie tak widzę tę stronę internetową, że ona jest czarna i ma w sobie tylko ten jeden, jedno okno, w którym wyświetlają się informacje. I to budzi moje skojarzenia z tym teatrem. Nie wiem - może nie być zachęcające dla ludzi, którzy nie chodzą do tego teatru, właśnie przez to, że jest taka czarna i ponura" - użytkownik 4W2 o serwisie Krakowskiego Teatru Scena STU.

(Q 10) „[N]o ale to „Wyzwolenie” jakoś bardziej do mnie przemawia, (-), bo tam mamy jeszcze taki jakiś układ, taki tutaj sceniczny, (-)" - użytkownik 7W4.

\section{Czy serwis WWW musi oddawać charakter teatru?}

Badania własne oparto na wstępnym założeniu - serwisom WWW przypisano możliwości wspomagania realizacji poza-instrumentalnych potrzeb użytkownika, stąd, oprócz użyteczności i funkcjonalności, postanowiono uwzględnić w badaniu wartości hedonistyczne oraz przekaz symboliczny. W celu potwierdzenia słuszności tego założenia, zadano użytkownikom pytanie o funkcje, które ich zdaniem powinien realizować serwis WWW. W efekcie otrzymano katalog sześciu funkcji:

(1) archiwalnej/dokumentacyjnej

(2) edukacyjnej/kulturotwórczej

(3) informacyjnej

(4) oddawania charakteru teatru

(5) pragmatycznej

(6) promocyjnej.

W tym artykule uwagę poświęcono znaczeniu przekazu symbolicznego, rozumianego jako oddawanie charakteru teatru.

Opinie użytkowników odnośnie istotności przekazu symbolicznego serwisów WWW teatrów krakowskich były zróżnicowane. Można je ująć w ramach następujących postaw:

(1) sceptycyzm wobec możliwości oddawania charakteru teatru za pomocą serwisu WWW (np. Q11) 
(2) kompromis - serwis może oddawać charakter teatru, ale nie powinno to przesłaniać funkcji pragmatycznych i/lub informacyjnych serwisu (np. Q12)

(3) konieczność - serwis powinien lub nawet musi oddawać charakter teatru (np. Q13).

(Q 11) „Ciężko powiedzieć na podstawie samego serwisu, jakiego rodzaju jest to teatr, co... W żaden sposób serwis nie może tego powiedzieć. Normalnym jest, że marketing musi działać niezależnie od formy... w jaką ubrane są spektakle, jakiego rodzaju są tam robione produkcje. Marketing a scena często niewiele ma ze sobą wspólnego. Po prostu mamy opis spektaklu, mamy zdjęcia ze spektaklu i cała otoczka zrobiona przez marketing, a to, co jest opowiedziane często nie musi mieć żadnego związku, zresztą tak samo, jak z trailerami filmowymi - tutaj sobie coś mruga, najlepsze zdjęcia powybierane, najbardziej charakterystyczne, zrobiony jakiś krótki opis... <odgłos przewijania strony> więc no ciężko mi odpowiedzieć na to pytanie na podstawie serwisu. Moim zdaniem się nie da odpowiedzieć na takie pytanie na podstawie serwisu” - użytkownik 9A5.

(Q 12) „Myślę, że powinien na pewno w jakiś sposób oddawać charakter teatru, tak jak ten Teatr Odwrócony, ale nie powinno to przysłaniać tych funkcji... dla których tak naprawdę, wydaje mi się, wchodzimy na stronę teatru, czyli że chcemy kupić bilet, sprawdzić terminy spektakli itd., więc... No, jest fajnie, kiedy to pasuje, ten serwis do danego teatru, ale powinno się też dać właśnie zrobić to, co najważniejsze, tak" - użytkownik 2A2.

(Q 13) „Musi oddawać charakter, musi - w takim mieście, jak Kraków, musi oddawać charakter teatru, dlatego że teatrów w Krakowie jest więcej i ta strona po prostu nie może sobie tak wisieć. Ona musi do kogoś przemawiać i teatry no wyrabiają sobie swoją taką, taką wierną publiczność wśród ludzi z Krakowa, chociaż... chociaż wiem, że coraz mniej akurat krakowian chodzi do teatru, a coraz więcej osób przyjezdnych" - użytkownik 4W2.

Użytkownicy poszukali elementów potwierdzających wyobrażenia o danym teatrze m.in. w opisach, zarówno teatru, jak i spektakli oraz w materiałach wizualnych, takich jak zdjęcia i/lub multimedia. Dla niektórych użytkowników ważne było, gdy materiały wizualne przedstawiały wnętrze i fasadę teatru, inni natomiast zwracali większą uwagę na materiały ukazujące fragmenty spektakli, gdyż na ich podstawie próbowali rozpoznać konwencję, jaką posługuje się dany teatr.

Zidentyfikowano różne poziomy wyobrażeń - począwszy od powierzchownych, które związane są m.in. z lokalizacją teatru oraz konkretnymi osobami, przez abstrakcyjne (jak np. ryzyko i nieokreśloność kojarzące się użytkownikowi 2A2 z Teatrem Odwróconym), aż do elementów na tyle silnie zakorzenionych w świadomości odbiorców (np. wybrane logotypy), że funkcjonują one niezależnie od całości serwisów i ocena ich spójności z serwisem WWW staje się niemożliwa. Użytkownicy najczęściej odszukiwali w badanych serwisach WWW powierzchowne skojarzenia, stąd otwarte pozostaje pytanie o to, na ile możliwe jest oddanie charakteru teatru za pomocą serwisów WWW w przypadku bardziej abstrakcyjnych wyobrażeń.

Ocena trafności przekazu symbolicznego serwisów WWW zależna była od wiedzy i doświadczenia użytkownika, co szczególnie widoczne było na przykładzie serwisów Teatru Odwróconego oraz Opery Krakowskiej. Kolejnym z indywidualnych czynników wpływających na możliwość analizy przekazu symbolicznego serwisu było nastawienie 
emocjonalne użytkowników. Zaobserwowano kilka kategorii wrażeń emocjonalnych i poznawczych, doświadczanych przez użytkowników podczas badania serwisów WWW teatrów krakowskich: odniesienia do wrażeń dotyczących świata realnego, wrażenia wynikające z interakcji z serwisem oraz wrażenia wywołane sytuacją badania i wrażenia nie wyrażone podczas werbalizacji. Tylko część z nich można zakwalifikować do UX serwisów WWW.

Nie sposób omówić w tym artykule trudności napotykanych przez użytkowników podczas interakcji z serwisami. Wiązały się one m.in. z procesem zakupu i informowaniem o dostępności biletów, obecnością i poprawnością działania wyszukiwarki, przejrzystością i klarownością etykiet i opisów, aktualizacją treści, nadmiarem bądź niekompletnością informacji, a wreszcie nieprzewidywalnością serwisu. Istotne jest to, iż użyteczność bywała wiązana z przekazem symbolicznym (np. Q14):

(Q 14) „Na pewno nie Teatr Variété - róbmy drogą eliminacji - strasznie mi się nie podoba to, że nie widzę dwóch pierwszych literek, bo ktoś genialnie umieścił biały napis na jasnym tle. Od razu mi się wydaje, że skoro napisu dobrze nie potrafią zrobić, nie zadowolą mnie, jeżeli chodzi o sztukę" - użytkownik 10W5.

W wypowiedzi Q14 oraz w opisie przekazu symbolicznego Teatru STU zaznaczono, że negatywne wrażenia związane z użytecznością serwisu, mogą być włączone przez użytkownika w ocenę przekazu symbolicznego serwisu i sprzyjać niekorzystnej dla teatru interpretacji (Q6). Nie jest to zaskakujące twierdzenie. W trakcie badań zauważono również zależność w drugą stronę, tj. pozytywnej ocenie wartości pragmatycznych towarzyszyła luka w przekazie symbolicznym. Najwyraźniej zauważono to w wypowiedziach użytkowników 4W2, 6A3 i 2A2. Dwie pierwsze dotyczyły serwisu Teatru Variété, zaś trzecia serwisu Teatru Odwróconego. W każdym z tych przypadków użyteczność serwisu została przez użytkowników oceniona pozytywnie, natomiast w ogólnym odbiorze serwisu brakowało jakiegoś elementu oddającego wyobrażenia użytkownika o danym teatrze. Użytkownik 2A2, podczas całego badania, podkreślał swój sceptycyzm wobec możliwość pełnienia przez serwis WWW funkcji oddawania charakteru teatru, zaś jedynym odstępstwem od tej tezy, była właśnie ogólna ocena serwisu Teatru Odwróconego. Zdanie uzasadniał odwołaniem do teorii czystej formy Witkacego, na której opiera się Teatr Odwrócony (Q15, Q16):

(Q 15) „Teoria czystej formy to jest taka teoria, która mówi, że widz, który ogląda spektakl, ogląda dramat... powinien doznać takich wewnętrznych jakichś uczuć, że po wyjściu ze spektaklu... powinien mieć takie poczucie, że brał udział w jakimś takim nieuchwytnym, bardzo dziwnym zdarzeniu, które miało go, w jakiś sposób tam, właśnie, oczyścić. Na tej zasadzie" - użytkownik 2A2 o Teatrze Odwróconym.

(Q 16) „Korzysta się z niego bardzo wygodnie, ale... Właśnie przez to, że korzysta się z niego tak bardzo wygodnie, to czegoś mi tutaj brakuje. Teraz mi przyszło do głowy, że gdyby tu był jakiś motyw przewodni, muzyczny właśnie taki... może jakiś Teatru Odwróconego... to, czy on by nie zaburzył tej właśnie takiej hm... zasady czystości przestrzeni na tej stronie, tak bym to nazwał" - użytkownik 2A2 o serwisie Teatru Odwróconego. 


\section{Wnioski}

Opisane w artykule badanie stanowiło próbę zapełnienia luk w piśmiennictwie naukowym z zakresu przekazu symbolicznego serwisów internetowych oraz User Experience serwisów teatrów. Przedstawiony został katalog sześciu funkcji przypisywanych serwisom WWW oraz zarysowano zależności między wartościami pragmatycznymi UX a przekazem symbolicznym. Do czynników wpływających na przekaz symboliczny zaliczono cechy indywidualne użytkownika, takie jak doświadczenie i wiedza oraz nastawienie emocjonalne, a także elementy wnoszone przez interakcję użytkownik-serwis, reprezentowane m.in. przez użyteczność, przy czym pozytywnej ocenie użyteczności serwisu niekoniecznie towarzyszy oczekiwany przekaz symboliczny.

Prowadzone są dalsze badania nad rozszerzoną definicją przekazu symbolicznego i jego wpływem na zachowania informacyjne użytkowników serwisów WWW.

\section{Bibliografia}

AlRoobaea, R. S.; Al-Badi, A. H.; Mayhew, P. J. (2013). Generating a Domain Specific Inspection Evaluation Method through an Adaptive Framework: A Comparative Study on Educational Websites. International Journal of Human Computer Interaction, 4(2), 88-116.

Bargas-Avila, J. A.; Hornbæk, K. (2011). Old Wine in New Bottles or Novel Challenges? A Critical Analysis of Empirical Studies of User Experience. Proceedings of the SIGCHI Conference on Human Factors in Computing Systems, 2689-2698.

Bhui, K.; Ibrahim, Y. (2013). Marketing the "radical": Symbolic communication and persuasive technologies in jihadist websites. Transcultural Psychiatry, 50(2), 216-234.

Coursaris, C. K.; Swierenga, S. J.; Pierce, G. L. (2010). Effects of Aesthetics and Playfulness on Web Usability - An empirical investigation. Americas Conference on Information Systems 2010 Proceedings [online], paper 549, AIS Electronic Library [21.06.2017], http://aisel.aisnet.org/amcis2010/549/

Diefenbach, S.; Hassenzahl, M. (2011). The dilemma of the hedonic - Appreciated, but hard to justify. Interacting with Computers, 23(5), 461-472.

Elling, S.; Lentz, L.; Jong, M. de (2012). Combining Concurrent Think-Aloud Protocols and Eye-Tracking Observations: An Analysis of Verbalizations and Silences. IEEE Transactions On Professional Communication, 55(3), 206-220.

Haak, M. J. van den; Jong, M. de; Schellens, P. J. (2009). Evaluating municipal websites: A methodological comparison of three think-aloud variants. Government Information Quarterly, 26(1), 193-202.

Hager, M. A.; Kopczynski-Winkler, M. (2012). Motivational and Demographic Factors for Performing Arts Attendance Across Place and Form. Nonprofit and Voluntary Sector Quarterly, 41(3), 474-496.

Helfenstein, S. (2012). Increasingly emotional design for growingly pragmatic users? A report from Finland. Behaviour E Information Technology, 31(2), 185-204.

Hernik, J. (2012). Morfologia marki organizacji niekomercyjnych na przykładzie polskich teatrów. Zeszyty Naukowe Uniwersytetu Szczecińskiego. Problemy Zarzadzania, Finansów i Marketingu, 24, 303-316.

Karapanos, E.; Zimmerman, J.; Forlizzi, J.; Martens J.-B. (2009). User experience over time: an initial framework. Proceedings of the SIGCHI Conference on Human Factors in Computing Systems, 729-738.

Kossecki, P.; Świerczyńska-Kaczor, U. (2014). Acquiring a Digital Audience for Theaters - Looking Through The Lenses of Customer Equity and Empirical Research. Proceedings of the 2014 Federated Conference on Computer Science and Information Systems, 1277-1284.

Laskowski, M. (2011). Czynniki zwiększające jakość użytkową interfejsów aplikacji internetowych. Logistyka, 6, 2191-2199. 
Nawaz, A. (2013). Website user experience: A cross-cultural study of the relation between users' cognitive style, context of use, and information architecture of local websites [online]. Copenhagen Business School Handelshøjskolen [21.06.2017], http://openarchive.cbs.dk/handle/10398/8871

O'Brien, H. L. (2010). The influence of hedonic and utilitarian motivations on user engagement: The case of online shopping experiences. Interacting with Computers: Special Issue on User Experience, 22(5), 344-352.

Pallud, J.; Straub, D. W. (2014). Effective website design for experience-influenced environments: The case of high culture museums. Information \& Management, 51(3), 359-373.

Partala, T.; Kallinen, A. (2011). Understanding the most satisfying and unsatisfying user experiences: Emotions, psychological needs, and context. Interacting with Computers, 24(1), 25-34.

Riley-Huff, D. A. (2009). Design Insights and Inspiration from the Tate: What Museum Web Sites Can Offer Us. Libraries and the Academy, 9(1), 79-98.

Sajkiewicz, V. (2010). Teatr w świecie widowisk. W: E. Wąchocka (red.) Widowisko - teatr -dramat: skrypt dla studentów kulturoznawstwa. Katowice: Wydaw. Uniwersytetu Śląskiego, 21-38.

Saucken, C. von; Gomez, R. (2014). Unified user experience model enabling a more comprehensive understanding of emotional experience design. Proceedings of the 9th International Conference on Design and Emotion: The Colors of Care, 631-640.

Schuitema, G; Anable, J.; Skippon, S.; Kinnear, N. (2013). The role of instrumental, hedonic and symbolic attributes in the intention to adopt electric vehicles. Transportation Research Part A-Policy and Practice, 48, 39-49.

Siwiak, A; Burszta, W.; Duniec, K.; Guderian-Czaplińska, E.; Wittels, K. (2013). Badanie publiczności teatrów w stolicy [online]. Narodowe Centrum Kultury [21.06.2017], http://www.nck.pl/bazabadan/302562-2013-badanie-publicznosci-teatrow-w-stolicy/

Szóstek, A. (2011). Metody ilościowe i jakościowe w dyscyplinie interakcja człowiek-komputer. Zeszyty Naukowe Politechniki Poznańskiej. Organizacja i Zarzadzanie, 56, 93-107.

Troilo, G.; Cito, M. C.; Soscia, I. (2014). Repurchase Behavior in the Performing Arts: Do Emotions Matter without Involvement? Psychology \& Marketing, 31(8), 635-646.

Trosheva, N. (2013). The Royal Opera House Website Evaluation Report [online]. Kingston University [21.06.2017], http://ninatrosheva.com/assets/files/ROH_Evaluation_Report.pdf

Turrini, A.; Soscia, I.; Maulini, A. (2012). Web communication can help theaters attract and keep younger audiences. International Journal of Cultural Policy, 18(4), 474-485.

Wu, J.; Holsapple, C. W. (2014). Imaginal and emotional experiences in pleasure-oriented IT usage: A hedonic consumption perspective. Information \& Management, 51(1), 80-92.

Yamin M.S.; Jaafar E.A. (2013). Web Design for Science Museum towards Engaging User Experience. In: Kotzé P., Marsden G., Lindgaard G., Wesson J., Winckler M. (eds) Human-Computer Interaction - INTERACT 2013. INTERACT 2013. Lecture Notes in Computer Science. Berlin: Heidelberg: Springer, 745-754.

Zaltman, G. (1996). Metaphorically speaking. Marketing Research, 8(2), 13-20.

\title{
Symbolic Messages and User Experience Approach Exemplified with the Websites of Cracow Theaters
}

\begin{abstract}
Purpose/Thesis: The purpose of the article was to investigate symbolic messages and User Experience approach in the case of the websites of Cracow theaters. The websites were claimed to support users' non-instrumental needs.
\end{abstract}


Approach/Methods: The study was conducted by means of qualitative research. Data were gathered with TAP and the technique based on ZMET. Ten users participated in the study and all of them had some theater background. Nine theater websites were chosen for the study. All empirical material was examined with thematic analysis.

Results and conclusions: Symbolic messages were depicted based on the Theater Scena STU website. The user's individual characteristics, emotional attitude and elements brought by the user-website interaction were found to be the factors influencing the symbolic messages. It was discovered that the positive assessment of the website usability does not necessarily lead to the expected symbolic message. Originality/Value: The article is intended as a contribution to further research on the relations between symbolic messages, informative messages and the usability of websites, which have not been studied in the information science so far.

\section{Keywords}

Function of website. Symbolic message. Theater website. Usability. User Experience.

MAGDALENA ZYCH jest absolwentka Instytutu Informacji Naukowej i Bibliotekoznawstwa Uniwersytetu Jagiellońskiego. Od roku akad. 2016/17 jest doktorantka informatologii i bibliologii na Wydziale Zarzadzania i Komunikacji Społecznej UJ. Zajmuje się problematyka użytkowników serwisów internetowych.

Kontakt $z$ autorka:

magdalena.zych@student.uj.edu.pl

Wydziat Zarzadzania i Komunikacji Społecznej

Uniwersytet Jagielloński

ul. prof. Stanistawa Łojasiewicza 4

30-348 Kraków 